ISSN : $1410-7252$

Vol. 18 No. 01 Juni 2016

\title{
OSOB NGALAMAN (BAHASA SLANG ASAL MALANG) SEBAGAI SALAH SATU I-CON MALANG (Studi Struktur Osob Ngalaman, dalam Sosial Network)
}

\author{
Aji Setyanto, M.Litt, \\ Universitas Brawijaya Malang \\ Jl. Veteran Kota Malang
}

Korespodensi dengan Penulis:

Adji Setyanto: Telp: 081333216379

E-mail: adjie_brawijaya@yahoo.co.jp

\begin{abstract}
Malang raya as a place of a tourist destination, must always be innovating and innovation to keep the existence and increase the appeal for tourists. One thing that should not be forgotten is that Malang has Osob Ngalaman or language Malangan. That language has two the main characteristics namely: typical language Malang / the dialect of malang (osob ngalaman) and their language Walikan. Both are fused and inseparable in language usage, both in oral and written. This research is a qualitative descriptive study aims to determine the dialect Malangan covering the structure of words, phrases and grammatical structure of the language used by people in the social network community. These results indicate that the structure of the word in Osob Ngalaman, there are variety of structures, even there is no rule of words between the speakers and the other said flipping the different words. In addition to reverse the order of the letters in the words, in Osob Ngalaman also contained original words such as Genaro, Lawet, Sibun. OsobNgalaman used the words of a language, 2 or even 3 languages (Java, Bahasa, and English). There are sentences that all words are reversed. Generally, not all the words revesed. Number of words that reversed also varies its speakers depends. For the benefit of tourism promotion and sustainability Osob Ngalaman it is necessary to stipulate or established institution OSOB NGALAMAN CENTER. It has a duty major: documenting Osob Ngalaman; conducted a study of continuous to the development of Osob Ngalaman; Formulating simple textbook, making a Osob Ngalaman dictionary; became the central of learning Osob Ngalaman; designing and planning to using Osob Ngalaman as means of Malang tourism promotion.
\end{abstract}

Keywords: Walikan Language, Malangan Dialect, Osob Ngalaman, Tourism

\begin{abstract}
Abstraksi
Malang raya sebagai salah satu tujuan wisata harus selalu berinovasi untuk menjaga eksistensinya dan menambah jumlah wisatawan yang datang. Satu hal yang tidak boleh dilupakan adalah kota Malang memiliki Osob Ngalaman atau Bahasa Malangan. Bahasa ini memilik dua ciri utama yaitu: Bahasa Malang itu sendiri/dialek malangan (osob ngalaman) dan bahasa Walikan. Keduanya bergabung dan tidak dapat dipisahkan dalam penggunaan bahasa Walikan baik secara lisan maupun tertulis.Penelitian deskriptif kualitatif ini bertujuan untuk menentukan dialek malangan yang terdiri dari struktur kata, frasa dan struktur bahasa yang digunakan oleh masyrakat sosial. Hasil dari penelitian ini menunjukkan bahwa dalam Osob Ngalaman memilik banyak struktur, walaupun
\end{abstract}


sebenernya tidak ada aturan antara penutur dalam membalikkan atau mengucapkan bahasa walikan yang berbeda. Untuk membalikkan susunan huruf dalam sebuah kata dalam bahasa Malangan biasanya juga masih menggunakan bahasa aslinya seperti Genaro, Lawet, Sibun. Osob Ngalaman menggunakan katakata dari 2 atau bahkan 3 bahasa (Jawa, Indonesia, dan Inggris). Kadang ada juga kalimat yang semua kata-katanya dibalik. Pada umumnya, tidak semua kata dalam Osob Ngalaman dibalik. Jumlah banyaknya kata-kata yang dibalik juga bergantung pada penuturnya itu sendiri.Sebagai bahan promosi yang berkelanjutan, Osob Ngalaman perlu ditetapkan atau dibuatkan OSOB NGALAMAN CENTER yang tugas utamanya adalah untuk medokumentasikan Osob Ngalaman dibarengi dengan studi yang berkelanjutan untuk mengembangakn Osob Ngalaman; memformulasikan textbook sederhana; membuat kamus Osob Ngalaman; membuat pusat belajar Osob Ngalaman; merancang dan merencanakan penggunaan Osob Ngalaman sebagai salah satu promosi wisata.

Kata kunci: Bahasa Walikan, Osob Ngalaman, Dialek Malangan, Pariwisata

Malang raya sebagai tempat tujuan wisata, harus selalu berbenah diri dan berinovasi untuk tetap menjaga eksistensi maupun meningkatkan daya tarik kepada para wisatawan. Hal yang bisa dilakukan selain melakukan promosi yang terus menerus, juga perlu adanya penggalian potensi untuk meninggalkan kesan maupun menunjukan ciri khas Malang, baik melalui kulinernya, kesenian lokalnya, maupun kebudayaan lainnya. Satu hal yang tidak boleh dilupakan adalah bahwa Malang punya Osob Ngalaman atau Bahasa Malangan atau yang lebih dikenal dengan Bahasa Walikan yang merupakan ciri khas Malang.
Untuk mengangkat Osob ngalaman ini perlu adanya penggalakan penggunakan dalam promosi wisata, papan-papan iklan maupun semua penggunaan yang berifat umum, yang saat ini sudah dimulai dibeberapa wilayah tertentu. Tetapi hal itu belum cukup, karena masih perlu adanya studi lebih lanjut tentang Osob Ngalaman itu sendiri, terutama proses pembentukkanya secara ilmu bahasa.

Studi ini meliputi bagaimana proses perubahan pembentukan kata, frase, maupun struktur gramatikalnya?. Apabila hal ini bisa terumuskan dengan baik, maka wisatawan akan muda mempelajari Osob Ngalaman dan akan menimbulkan 
kesan khas Malang yang mendalam. Untuk kepentingan studi Osob Ngalaman ini diambil data dari penggunaan Osob Ngalaman oleh para penutur dalam komunitas-komunitas dalam Social Network. Yang kemudian diteliti dengan menggunakan metode penelitian kualitatif deskriptif.

\section{Struktur Bahasa}

Struktur adalah susunan bagian-bagian satuan secara linier. Di dalam bahasa, struktur dapat dibedakan menurut sistematis bahasanya, yaitu menurut susunan fonetis, morfemis, dan sitaksis (Chaer, 2007:52). Oleh karena itu, apabila suatu ujaran dianalisis, maka ujaran itu pertama-tama dapat disegmentasikan atas satuan fonologi, morfologi, sintaksis, dan wacana/paragraf. Struktur satuansatuan sintaksis, meliputi struktur kalimat, struktur klausa, struktur frase, dan struktur kata (Chaer, 2007:59).

Dari keempat satuan sintaksis tersebut, kami akan menjadikan struktur kalimat, struktur frase, dan struktur kata sebagai objek kajian/penelitian. Pada Struktur kalimat salah satu yang akan dianalisis adalah apakah ada pergeseran urutan fungsi dari unsur-unsur pembangun kalimat? Pada strutur frase, seperti apakah hubungan unsur-unsur pembentuknya? Dan pada struktur kata, akan dianalisis kedudukannya dalam kalimat, serta adakah pelesapan dari salah satu kata pengisi fungsi sintaksis dalam Osob Ngalaman?

\section{Variasi Bahasa}

Perbedaan bahasa menghasilkan ragam-ragam bahasa yang disebut dengan istilah-istilah yang berlainan. Berikut ini terdapat istilah-istilah yang sering digunakan dalam variasi bahasa dari segi penutur menurut Chaer dan Agustina (2004, 62-65):

1. Idiolek merupakan variasi bahasa yang bersifat perseorangan. Idiolek ini berkenaan dengan warna suara, pemilihan diksi, bahasa, susunan kalimat, dan juga ekspresi.

2. Dialek merupakan variasi bahasa dari sekelompok penutur yang jumlahnya relatif, 
yang berada pada tempat atau area tertentu.

3. Kronolek merupakan variasi bahasa yang digunakan oleh sekelompok social pada masa tertentu sesuai dengan perkembangan jaman.

4. Sosiolek merupakan variasi bahasa yang berkenaan dengan status, golongan, dan kelas social parapenuturnya.

Sehubungan dengan variasi bahasa yang berkenaan dengan tingkat, golongan, dan status penuturnya. Chaer dan Agustina (2004, 65-68), membagi menjadi 8 bagian yaitu:

1. Akrolek merupakan variasi bahasa yang dianggap lebih tinggi dari pada variasi social lainnya.

2. Basilek merupakan variasi bahasa yang dianggap kurang bergengsi atau dipandang rendah.

3. Vulgar merupakan variasi bahasa yang ciri-ciri penuturnya adalah golongan orang yang kurang terpelajar.
4. Slang merupakan variasi bahasa yang bersifat khusus dan rahasia.

5. Kolokial merupakan variasi bahasa yang digunakan dalam percakapan sehari-hari.

6. Jargon merupakan variasi bahasa yang digunakan secara terbatas oleh kelompok social tertentu, tidak bersifatr ahasia.

7. Argot merupakan variasi bahasa yang digunakan secara terbatas pada profesi tertentu dan bersifat rahasia.

8. Ken merupakan variasi bahasa yang bernada "memelas", dibuat merengek-rengek penuh dengan kepura-puraan.

Berdasarkan variasi dari segi penutur, Osob Ngalaman merupakan sebuah dialek, dikarenakan digunakan oleh sekelompok penutur di daerah Malang JawaTimur. Dalam variasi bahasa menurut tingkat golongan, status, dan kelas social penuturnya, bahasa Malangan termasuk ke dalam bahasa Slang, karena bersifat khusus dan rahasia.

\section{Pengertian Bahasa Slang}


Menurut Chaer dan Agustina (2004:67) yang dimaksud dengan slang adalah variasi sosial yang bersifat khusus dan rahasia, variasi ini digunakan oleh kalangan tertentu dan sangat terbatas dan tidak boleh diketahui oleh kalangan diluar kelompok tersebut. Selain bersifat khusus dan rahasia bahasa slang juga bersifat temporal. Hal ini sesuai pendapat Davito (1997), slang biasanya berumur pendek meski beberapa istilah dapat bertahan dan terserap ke dalam bahasa sebagai ungkapan yang secara sosial dapat diterima. Oleh karena itu kosakata yang digunakan pun selalu berubahubah sesuai perubahan sosial yang mempengaruhi perkembangan bahasa. Pengguna Bahasa Slang Malang/Bahasa Malangan sebagian besar adalah masyarakat Malang terutama mereka yang berusia muda, termasuk mahasiswa pendatang yang datang ke Malang.Bahasa Malangan digunakan dalam kehidupan seharihari, misalnya ketika berkumpul bersama komunitasnya dan bahkan ketika berbicara dengan saudara dan kerabatnya.
Sejarah Terbentuknya Bahasa

\section{Malangan}

Menurut pendapat beberapa kalangan dan para sejarahwan yang tertuang dalam turuntanganmlg.wordpress.com ${ }^{1}$, bahasa Malangan khususnya bahasa walikan memiliki nilai historis perjuangan masyarakat Malang ketika melawan penjajah Belanda. Bahasa walikan Malangan tersebut dipelopori oleh salah seorang pejuang yang bernama Suyudi Raharno, seorang pejuang Gerilya Rakyat Kota (GRK).

GRK adalah gerakan perjuangan rakyat Malang yang bersifat rahasia dan tersembunyi. Ketika penjajah Belanda menyadari adanya gerakan ini dan menyulitkan penjajah dengan serangkaian perlawanannya. Belanda pun mencari beberapa pribumi Jawa untuk direkrut menjadi mata-mata belanda. Adanya mata-mata menyebabkan banyak informasi penting yang dimiliki GRK bocor ke tangan penjajah Belanda. Hal ini membuat beberapa serangan para pejuang GRK dapat digagalkan dengan mudah oleh Belanda.

${ }^{1}$ https://turuntanganmlg.wordpress.com/2015/02/ 26/sejarah-awal-bahasa-walikan/ 
Setelah GRK menyadari adanya penyusup Belanda yang membocorkan informasi, maka GRK berunding menyusun strategi agar kerahasiaan informasi tetap aman dari mata-mata, lalu muncullah ide untuk membuat bahasa sandi. Yang kini dikenal dengan bahasa walikan, yaitu bahasa Jawa yang dibalik struktur katanya untuk mencegah kebocoran informasi ke pihak belanda. Ide ini dinilai sangat efektif, karena setelah penggunaan bahasa walikan para pejuang dapat menemukan mata-mata Belanda. Beberapa dari mereka menyamar sebagai penjual di pinggir jalan dan di pasar, atau sebagai pekerja di warungwarung.Anggota GRK pun akan dicurigai sebagai mata-mata jika tidak mengetahui bahasa sandi yang diperbaharui setiap hari.

Rasa persaudaraan dan loyalitas yang tinggi antar sesama pejuang merupakan faktor utama meluasnya penggunaan bahasa walikan pada saat itu. Penggunaan bahasa walikan ini tidak berhenti walau Indonesia sudah merdeka dari penjajah.
Pengguna dan Fungsi Bahasa

\section{Malangan di Masa Kini}

Bahasa merupakan wahana komunikasi utama manusia. Dalam arti luas, bahasa memiliki dua ciri utama. Pertama; digunakan dalam proses transmisi pesan. Kedua; merupakan kode yang penggunaannya ditentukan bersama oleh warga suatu masyarakat (Sihabudin, 2011:77). Ini berarti, bahasa merupakan suatu aspek kehidupan sosial manusia. Digunakan dalam kehidupan kesehariannya. Demikian juga dengan bahasa Malangan dalam penelitian ini.

Menurut Soenarno, (2010) fungsi Bahasa Malangan antara lain:

a) Identitas diri. Bahasa Malangan muncul dari semangat persaudaraan dan loyalitas terhadap tanah air, dan juga sebagai simbol identitas masyarakat kota Malang. Sehingga merupakan kebanggaan jika bertemu orang Malang di berbagai penjuru dunia, atau minimal bagi orang yang pernah tinggal, sekolah, bekerja di Malang. Mereka akan mencoba bertegur sapa dan menunjukkan beberapa kosa kata 
yang mereka tahu untuk membuka percakapan.

b) Menjaga semangat cinta tanah air. Tidak hanya sekedar ingin menghargai para pejuang. Namun lebih dari itu, ingin selalu mengenang dan melanjutkan perjuangan para pendahulunya melalui kata dan bahasa seraya berharap bahwa semangat perjuangan itu tetap terjaga.

c) Menjalin keakraban. Sebagai bahasa tingkat tinggi, untuk pejabat, businessman, dan kaum profesional - apalagi jika fasih menggunakan bahasa walikan, akan saling mendekatkan hubungan mereka untuk urusan bisnis dan masalah penting.

d) Kebanggaan tersendiri. Ada anggapan bahwa orang yang bisa berbicara dengan bahasa walikan rata-rata adalah orang cerdas, karena sambil berbicara, pikiranya terus berputar, dengan cepat bisa menemukan kebalikan kata-kata yan akan diucapkan. Jika orang ingin lancar bicara dan memakai kata walikan yang umum, itupun juga tergolong cerdas - karena mengarahkan pembicaraan yang bermakna tetapi menyertakan kata yang dihafal untuk dibalik dan dengan bangga menyebutkannya. Orang tua, pedagang, pemuda, pelajar anak kecil dan anak sekolah merasa senang mempunyai sebuah skill dan identitas khas jika bisa berbahasa walikan. Ada yang menyisipkan beberapa saja kata walikan dalam percakapan atau penuturan tertulis, tetapi ada yang sebagian besar semua kalimatnya terdiri dari bahasa walikan. Ada yang mengulang dengan kata biasa untuk memperjelas, tetapi ada pula yang asal membalik kata walaupun terasa janggal dan tidak popular.

\section{STRUKTUR OSOB NGALAMAN} (Studi Kasus Penggunaan dalam Social Network)

Bahasa Malangan yang memiliki dua ciri utama, yaitu: Bahasa khas Malang/dialek Malang (Osob Ngalaman) dan Bahasa Walikan (Osob Kiwalan). Keduanya menyatu/tidak terpisahkan dalam pemakaian bahasa, baik dalam bahasa lisan maupun bahasa tulisan. ${ }^{2}$

(https://www.facebook.com/groups/18021853202 1941/?fref=ts: diakses 09 Juni 2015: 00.01) 
Bahasa Malangan ini pada umumnya digunakan oleh masyarakat sebagai bahasa Slang, dalam berbagai komunitas yang ada di kota Malang. Banyak sekali komunitas yang terbentuk oleh kesamaan identitas, hobi, kepentingan, minat, kondisi hidup, pekerjaan kebutuhan, dan sebagainya. Komunitas tersebut antara lain, adalah group-group dalam Sosial Network yang salah satunya adalah Group OSOB NGALAMAN yang memang bertujuan mewadahi siapapun yang ingin berkomunikasi dalam bahasa Slang Malangan.

Salah satu Contoh penggunaan bahasa Malangan atau Osob Ngalaman tersebut adalah sebagai berikut

\section{Mohamad Nurhuda}

27 September 2013

RUTAM NUWUS SAM NGADAD, , HELO NGUBAG ked GRUP.

\#MALAS UTAS AWIJ\# AE SAM..! :;

Suka Bagikan

"RUTAM NUWUS SAM NGADAD,", HELO NGUBAG ked GRUP.. \#MALAS UTAS AWIJ\# AE SAM"

"Matur Nuwun Mas Dadang, Oleh gabung ke Grup. \#Salam Satu Jiwa\#" "Terima kasih Mas (Kak) Dadang. Boleh gabung ke Grup. \#Salam Satu Jiwa\#"

Dalam data 1 ini bisa di cermati adanya penggunaan bahasa Malangan yang berasal dari bahasa Jawa :"Rutam nuwus, sam Ngadad,", helo dan bahasa Indonesia "Malas Utas Awij" , Sistem dalam membalik huruf nya pun ternyata bervariasi.

- Ada kata - kata yang langsung dibalik susunan huruf dari bahasa asalnya seperti:

Sam = Mas (Panggilan Kak terhadap laki-laki)

$$
\begin{array}{ll}
\text { helo } & =\text { oleh (boleh) } \\
\text { malas } & =\text { salam } \\
\text { utas } & =\text { satu } \\
\text { awij } & =\text { jiwa }
\end{array}
$$

- Kata majemuk dengan susunan huruf terbalik tetapi susunan kata tidak berubah :

rutam nuwus $=$ matur suwun (terima kasih),

- Ada kata yang sebagian hurufnya tidak dibalik

$$
\begin{aligned}
& \text { ngadad }=\text { Dadang (nama } \\
& \text { orang) } \\
& \text { ngubag }=\text { Gabung }
\end{aligned}
$$

- Ada kata-kata yang tidak berubah susunannya (sama dengan bahasa Jawa pada umumnya)

$$
\begin{array}{ll}
\text { ae } & =\text { aja } \\
\text { ojo } & =\text { jangan } \\
\text { ora } & =
\end{array}
$$
tidak

Data 2 
"oyi jess.. odop2. Wis nakam opo durung? Lek ewul ndang nakamo.."

"Iyo Jess.. podo-podo. Wis makan opo durung? Lek luwe ndang makan o."

"Iya Jess.. sama-sama. Sudah makan apa belum? Kalau lapar cepat makan."

Dalam data 2 ini, penggunaan bahasa Malangan yang berasal dari bahasa Jawa :"'oyi, odop2.Wis, opo durung, Lek ewulndang nakamo.." dan bahasa Indonesia "nakam" serta kata yang bukan bersal dari kedua bahasa tersebut " jess, $o$.

Sistem dalam membalik huruf nya juga bervariasi.

- Ada kata - kata yang langsung dibalik susunan huruf dari bahasa asalnya seperti:

$$
\begin{aligned}
& \text { Oyi = iyo (iya) } \\
& \text { Odop-odop = podo-podo } \\
& \text { (sama-sama), } \\
& \text { Ewul = luwe (lapar) } \\
& \text { nakam = makan } \\
& \text { awij = jiwa }
\end{aligned}
$$

- Ada kata-kata yang susunan hurufnya tidak berubah

$$
\begin{aligned}
& \text { wis = sudah } \\
& \text { opo = apa } \\
& \text { durung }=\text { belum } \\
& \text { lek }=\text { kalau } \\
& \text { ndang=segera }
\end{aligned}
$$

Dari dua contoh pemakaian bahasa Malangan di atas, adanya pemakaian lebih dari satu bahasa, ada susunan pembalikan huruf yang bervariasi, serta penggunaan kata-kata yang tidak berasal dari bahasa Jawa ataupun bahasa Indonesia.

\section{HASIL PENELITIAN}

Dari hasil pencarian data diberbagi komunitas social network (Face book) ditemukan 43 kalimat, kemudian diklasifikasikan menjadi 38 kalimat, tidak semua kata-kata dalam kalimatnya dibalik dengan menggunakan Boso Malangan. Dan terdapat 5 kalimat yang seluruh katakata dalam kalimat tersebut dibalik dengan Boso Malangan. Proses pembalikan kata-katanya pun bervariasi, bahkan ditemukan dari asal kata yang sama dibalik dengan huruf atau ucapan yang berbeda. Lebih detail, temuan tersebut terangkum dalam klasifikasi tabel sebagai berikut: 


\section{Tabel Temuan:}

Keterangan : K : Konsonan V: Vokal

\begin{tabular}{|l|l|l|}
\hline $\begin{array}{l}\text { Kata yang dibalik langsung } \\
\text { seluruh hurufnya }\end{array}$ & $\begin{array}{l}\text { K1V1K2V2 } \\
\text { K1 } \rightarrow \text { V2 K2V1 }\end{array}$ & 159 Kata \\
\hline $\begin{array}{l}\text { Kata yang sebagian suku } \\
\text { katanya tidak dibalik }\end{array}$ & $\begin{array}{l}\text { K1K2V1K3K4V2 } \rightarrow \\
\text { V2K4K3V1K1K2 }\end{array}$ & 26 Kata \\
\hline Kata dibalik dengan imbuhan & $\begin{array}{l}\text { Imbuhan + K1V1K2V2 } \\
\text { Imbuhan + V2 K2V1 K1 } \\
\text { K1V1K2V2 + Imbuhan } \rightarrow \\
\text { V2 K2V1 K1 + Imbuhan }\end{array}$ & 13 Kata \\
\hline $\begin{array}{l}\text { Panggunaan dalam Nama } \\
\text { Tempat }\end{array}$ & & 3 Kata \\
\hline $\begin{array}{l}\text { Penggunaan dalam Nama DP } \\
\text { Penggunaan dalam Nama DP }\end{array}$ & & 6 kata \\
\hline $\begin{array}{l}\text { Kata Baru } \\
\text { Lainnya }\end{array}$ & Semua kalimat \\
\hline $\begin{array}{l}\text { Bahasa Campuran 2 bahasa } \\
\text { lebih }\end{array}$ & Semua kalimat \\
\hline $\begin{array}{l}\text { Tidak semua kata dalam } \\
\text { kalimat dibalik }\end{array}$ & 38 Kalimat \\
\hline $\begin{array}{l}\text { Semua kata dalam kalimat } \\
\text { dibalik }\end{array}$ & 5 kalimat \\
\hline
\end{tabular}

\section{STRUKTUR KATA DALAM OSOB}

\section{NGALAMAN}

Struktur kata dalam Osob ngalaman, ada berbagai macam struktur, bahkan karena tidak ada aturan dari kata yang sama antara penutur yang satu dan yang lainnya membalik kata dengan proses yang berbeda sehingga memunculkan kata yang berbeda.

\section{A. Kata yang dibalik langsung} seluruh hurufnya

$\left(\mathrm{K}_{1} \mathrm{~V}_{1} \mathrm{~K}_{2} \mathrm{~V}_{2} \mathrm{~K}_{3} \rightarrow \mathrm{K}_{3} \mathrm{~V}_{2} \mathrm{~K}_{2} \mathrm{~V}_{1} \mathrm{~K}_{1}\right)$

Berikut ini adalah kalimat Osob Ngalaman yang menggunakan kata- kata yang hurufnya ditulis atau dibaca dari belakang, atau dibalik seluruh hurufnya . Sehingga kata yang berstruktur $\mathrm{K}_{1} \mathrm{~V}_{1} \mathrm{~K}_{2} \mathrm{~V}_{2} \mathrm{~K}_{3}$ ditulis atau dibaca dari belakang menjadi kata $\begin{array}{llllll}\text { dengan strukur } K_{3} & V_{2} & K_{2} & V_{1} & K_{1} \text {. Dari }\end{array}$ seluruh data kata yang dibalik pengucapan dan penulisannya kata yang dibentuk dengan pola ini ada sejumlah 159 kata.

\section{Data 1}

“Numpang mejeng tok miin, reneb jarene konco q masio kunam osed panganane sak 
tompo seng penteng duwe, reneb ndak loor?"

“Numpang Mejeng saja Mind. Benar kata teman saya burung desa makannya sebakul, yang penting punya. Bener nggak saudara?"

Data 1 di atas, terdiri dari 2 bahasa yaitu bahasa Indonesia (Numpang, ndak) dan Bahasa Jawa (mejeng, tok, reneb, jarene, konco, q, masio, kunam, osed, panganane, sak, tompo, seng, penten, duwe, reneb, loor).

$\begin{array}{lll}\mathrm{B} \text { e n e r } & \rightarrow & \mathrm{R} \text { e e b } \\ \mathrm{K}_{1} \mathrm{~V}_{1} \mathrm{~K}_{2} \mathrm{~V}_{2} \mathrm{~K}_{3} & & \mathrm{~K}_{3} \mathrm{~V}_{2} \mathrm{~K}_{2} \mathrm{~V}_{1} \mathrm{~K}_{1} \\ \mathrm{M} \text { a n u k } & \rightarrow & \mathrm{K} \text { u a m } \\ \mathrm{K}_{1} \mathrm{~V}_{1} \mathrm{~K}_{2} \mathrm{~V}_{2} \mathrm{~K}_{3} & & \mathrm{~K}_{3} \mathrm{~V}_{2} \mathrm{~K}_{1} \mathrm{~K}_{1} \\ \mathrm{D} \text { e s o } & \rightarrow & \mathrm{O} \text { e d } \\ \mathrm{K}_{1} \mathrm{~V}_{1} \mathrm{~K}_{2} \mathrm{~V}_{2} & & \mathrm{~V}_{2} \mathrm{~K}_{2} \mathrm{~V}_{1} \mathrm{~K}_{1}\end{array}$

Ketiga kata yang masuk dalam Osob ngalaman tersebut strukurnya langsung dibalik dari belakang.

\section{Data 2}

"Nuwus sam, jo lali posting info sejarah ngalam neyib."

"Terima kasih Mas, jangan lupa posting info sejarah Malang jaman dahulu."

Data 2 terdiri dari 3 bahasa yaitu bahasa Indonesia (sejarah), bahasa Jawa (Nuwus, sam, jo lali, inf, neyib) dan bahasa Inggris (posting). Dar i 3 unsur bahasa tersebut yang dibentuk menjadi Osob ngalaman adalah (Nuwus, sam, dan neyib). (kata ngalam akan di bahas dalam sub bab berikutnya)

Kata Nuwus berasal dari bahasa Jawa Suwun yang artinya terima kasih.

Kata Sam berasal dari bahasa Jawa Mas yang artinya Kakak lakilaki (pemanggilan kepada laki-laki lain). 
Kata neyib berasal dari bahasa Jawa biyen yang artinya jaman dahulu.

$\mathrm{S}$ u w u n

$\mathrm{K}_{1} \mathrm{~V}_{1} \mathrm{~K}_{2} \mathrm{~V}_{2} \mathrm{~K}_{3}$

$\mathrm{M}$ a s

$\mathrm{K}_{1} \mathrm{~V}_{1} \mathrm{~K}_{2}$

B i y e $\mathrm{n}$

$\mathrm{K}_{1} \mathrm{~V}_{1} \mathrm{~K}_{2} \mathrm{~V}_{2} \mathrm{~K}_{3}$ $\rightarrow \quad \mathrm{Nu} \mathrm{w} \mathrm{u} \mathrm{s}$

$\mathrm{K}_{3} \mathrm{~V}_{2} \mathrm{~K}_{2} \mathrm{~V}_{1} \mathrm{~K}_{1}$

$\rightarrow \quad \mathrm{S} \mathrm{a} \mathrm{m}$

$\mathrm{K}_{2} \mathrm{~V}_{1} \mathrm{~K}_{1}$

Ketiga kata tersebut apabila dilihat dari asal katanya, pembentukannya adalah sebagai berikut:

$\rightarrow \quad \mathrm{N}$ e $\mathrm{y}$ i b

$\mathrm{K}_{3} \mathrm{~V}_{2} \mathrm{~K}_{2} \mathrm{~V}_{1} \mathrm{~K}_{1}$

Ketiga kata yang masuk dalam Osob ngalaman tersebut strukurnya langsung dibalik dari belakang.

\section{Data 3}

"Sam amunisi kk iki sek nayamul 80\% pengin barter kk e gae LB."

"Mas amunisi KK (Kandang Kerodong) ini, masih lumayan 80 \% ingin barter KK buat LB"

Data 3 terdiri dari 2 bahasa yaitu bahasa Indonesia (amunisi, barter, nayamul), bahasa Jawa (Sam,iki, sek, pengin, gae ). Dari 2 unsur bahasa tersebut yang dibentuk menjadi Osob ngalaman adalah (Sam dan Nayamul).

Kata Sam berasal dari bahasa Jawa Mas yang
$\mathrm{M}$ a s
$\rightarrow \quad \mathrm{S} \mathrm{a} \mathrm{m}$
$\mathrm{K}_{1} \mathrm{~V}_{1} \mathrm{~K}_{2}$
$\mathrm{K}_{2} \mathrm{~V}_{1} \mathrm{~K}_{1}$
$\mathrm{L} \mathrm{u}$ m a y a $\mathrm{n}$
$\rightarrow \quad \mathrm{N}$ a y a m u 1
$\mathrm{K}_{1} \mathrm{~V}_{1} \mathrm{~K}_{2} \mathrm{~V}_{2} \mathrm{~K}_{3} \mathrm{~V}_{3} \mathrm{~K}_{4}$

artinya Kakak lakilaki (pemanggilan kepada laki-laki lain). Kata nayamul berasal dari bahasa Indonesia lumayan.

Kedua kata tersebut apabila dilihat dari asal katanya, pembentukannya adalah sebagai berikut:

Kedua kata tersebut strukurnya langsung dibalik dari belakang. 


\section{Data 4}

"Up kunam kipa iki, kendel hare"

“Up burung bagus ini, pemberani lho".

Data 4 di atas, terdiri dari 2 bahasa yaitu bahasa Inggris $(U p)$ dan Bahasa Jawa (kunam, kipa, iki, kendel, hare). Dalam kalimat tersebut terdapat 2 kata yang dibalik sebagai Osob Ngalaman. Yaitu kata kunam, dan kipa.
Kata kunam berasal dari bahasa Jawa manuk yang artinya burung.

Kata kipa berasal dari bahasa Jawa apik yang artinya bagus.

Sehingga kalau dilihat dari asal katanya, pembentukannya adalah sebagai berikut:
$\mathrm{M}$ a $\mathrm{n}$ u $\mathrm{k}$

$\mathrm{K}_{1} \mathrm{~V}_{1} \mathrm{~K}_{2} \mathrm{~V}_{2} \mathrm{~K}_{3}$

A p i $k$

$\mathrm{V}_{1} \mathrm{~K}_{1} \mathrm{~V}_{2} \mathrm{~K}_{2}$

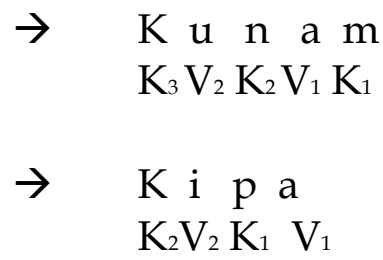

$\mathrm{K}_{2} \mathrm{~V}_{2} \mathrm{~K}_{1} \mathrm{~V}_{1}$

Kedua kata yang masuk dalam Osob ngalaman tersebut strukurnya langsung dibalik dari belakang.

B. Kata yang sebagian suku katanya tidak dibalik.

$\mathrm{K}_{1} \mathrm{~K}_{2} \mathrm{~V}_{1} \mathrm{~K}_{3} \mathrm{~K}_{4} \mathrm{~V}_{2} \rightarrow \mathrm{V}_{2} \mathrm{~K}_{4} \mathrm{~K}_{3} \mathrm{~V}_{1} \mathrm{~K}_{1} \mathrm{~K}_{2}$

Pola ke dua yang ditemukan dari proses pembentukan kata-kata dalam Osob Ngalaman data adalah sebagian struktur kata tidak dibalik atau tidak

\section{Data 5}

"Cari tt an jalak uret lokal, meskipun jik trotol gak popo pokok nganal."

"Cari tt an jalak uret lokal, meskipun jik trotol gak pa pa pokoknya jantan."

Dalam data 5 di atas, kalimatnya

dalam bahasa Indonesia dengan (nganal) yang ditulis dalam Osob

Ngalaman. berubah. Salah satu contohnya yaitu kata yang mempunyai pola $\mathrm{K}_{1} \mathrm{~K}_{2} \mathrm{~V}_{1} \mathrm{~K}_{3} \mathrm{~K}_{4} \mathrm{~V}_{2} \quad$ berubah menjadi $\mathrm{V}_{2} \mathrm{~K}_{4} \mathrm{~K}_{3} \mathrm{~V}_{1} \mathrm{~K}_{1} \mathrm{~K}_{2}$. Dari seluruh data yang ditemukan kata yang mempunyai pola seperti ini berjumlah 26 kata. sisipan bahasa Jawa (gak po po) dan 
Kata Nganal berasal dari kata

Lanang yang berarti Jantan.

Struktur pembentukan kata tersebut adalah sebagai berikut:
$\mathrm{L}$ a $\mathrm{n}$ a $\mathrm{n}$ g $\quad \mathrm{N}$ g a $\mathrm{n}$ a 1 $\mathbf{K}_{1} \mathrm{~V}_{1} \mathbf{K}_{2} \mathrm{~V}_{2} \mathrm{~K}_{3} \mathrm{~K}_{4} \quad \rightarrow \mathrm{K}_{3} \mathrm{~K}_{4} \mathrm{~V}_{1} \mathbf{K}_{2} \mathrm{~V}_{2} \mathbf{K}_{1}$ susunannya tidak dibalik tetap (ng) $K_{3}$ $\mathrm{K}_{4}$.

\section{Data 6}

"Nakam oges ngerog disek trs rudit lurd.."

"Makan nasi goreng dulu, terus tidur saudara"

Kalimat dalam data 6 di atas, menggunakan bahasa Indonesia, disisipi bahasa Jawa (disek sama lurd). Kalimat diatas terdapat beberapa kata yang dibalik, antara lain Nakam, oges, ngerog, rudit dan lurd. Satu kata yang proses pembalikannya ada yang strukurnya tidak dibalik yaitu kata ngerog.
Kata ngerog berasal dari bahasa Indonesia kata goreng.

Struktur pembentukannya adalah sebagai berikut:

$\mathrm{G}$ o $\mathrm{r}$ e $\mathrm{n} \mathrm{g} \rightarrow \mathrm{N}$ g e r o g $\mathrm{K}_{1} \mathrm{~V}_{1} \mathrm{~K}_{2} \mathrm{~V}_{2} \mathrm{~K}_{3} \mathrm{~K}_{4} \quad \rightarrow \mathrm{K}_{3} \mathrm{~K}_{4} \mathrm{~V}_{1} \mathbf{K}_{2} \mathrm{~V}_{2} \mathbf{K}_{1}$

Dari struktur di atas huruf (ng) $K_{3} K_{4}$ susunannya tidak dibalik tetap (ng) $K_{3}$ $\mathrm{K}_{4}$.

\section{Data 7}

"Tem ingeb ker, yokpo erabak arema ngalam ongis nade oy.."

“ Met malam kawan, Bagaimana kabarnya Arema Malang Singo Edan?"

Kalimat dalam data 7 , tidak dibalik yaitu kata ingeb, ngalam, menggunakan bahasa Indonesia dan ongis.

bahasa Jawa yang dibalik. Bahasa

Kata ingeb berasal dari bahasa Indonesia (erabak) Bahasa Jawa Jawa bengi yang artinya malam.

(Tem,ingeb, ker, yokpo). Hampir semua Kata ngalam merupakan Osob kata dalam kalimat diatas dibentuk menjadi Osob Ngalaman kecuali kata (yokpo). Kata yang proses Ngalaman dari nama kota Malang.

Kata ongis berasal dari bahasa pembalikannya ada yang strukurnya 
Struktur pembentukannya adalah

sebagai berikut:

$\begin{array}{ll}\mathrm{Sing} \mathrm{g} & \rightarrow \mathrm{Ong} \mathrm{i} s \\ \mathrm{~K}_{1} \mathrm{~V}_{1} \mathrm{~K}_{2} \mathrm{~K}_{3} \mathrm{~V}_{2} & \rightarrow \mathrm{V}_{2} \mathrm{~K}_{2} \mathrm{~K}_{3} \mathrm{~V}_{1} \mathrm{~K}_{1}\end{array}$

B e $\mathrm{n} \mathrm{g} \mathrm{i} \rightarrow \mathrm{I}$ n e b

$\mathrm{K}_{1} \mathrm{~V}_{1} \mathrm{~K}_{2} \mathrm{~K}_{3} \mathrm{~V}_{2} \rightarrow \mathrm{V}_{2} \mathrm{~K}_{2} \mathrm{~K}_{3} \mathrm{~V}_{1} \mathbf{K}_{1}$

Dari struktur di atas huruf (ng)

$\mathrm{K}_{2} \mathrm{~K}_{3}$ pada kata ingeb dan Ongis, $\mathrm{K}_{1} \mathrm{~K}_{2}$

$\mathrm{M}$ a 1 a n g $\rightarrow \mathrm{Ng}$ a 1 a m pada kata Ngalam tidak berubah dari $\mathrm{K}_{1} \mathrm{~V}_{1} \mathrm{~K}_{2} \mathrm{~V}_{2} \mathrm{~K}_{3} \mathrm{~K}_{4} \quad \rightarrow \quad \mathrm{K}_{3} \mathrm{~K}_{4} \mathrm{~V}_{1} \mathbf{K}_{2} \mathrm{~V}_{2} \mathbf{K}_{1}$ susunan struktur kata asalnya.

\section{Data 8}

"Mboiss lop iki nawak. Lek umak pengen itreng."

"Bagus sekali ini Kawan. Kalau kamu ingin ngerti."

Kalimat dalam data 8 , menggunakan bahasa Indonesia dan bahasa Jawa yang dibalik. Bahasa Indonesia (nawa) Bahasa Jawa (Mbois, lop, iki, Lek, umak, pengen, itreng."). Kata yang proses pembalikannya ada yang strukurnya tidak dibalik yaitu kata itreng.

Kata itreng berasal dari bahasa Indonesia kata Ngerti.

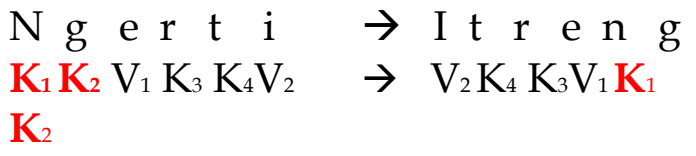

$\mathrm{K}_{1} \mathrm{~K}_{2}$ Pada kata Itreng tidak berubah dari susunan struktur kata asalnya.

Dari pembahasan pada Data 5,6,7,8, huruf yang tidak berubah tersebut adalah huruf (ng).
Kemungkinan alasan kenapa huruf (ng) tidak dibalik adalah :

1. Huruf (ng) dianggap sebagai 1 bunyi.

2. Huruf (ng) kalau dibalik menjadi (gn) yang tidak menghasilkan bunyi baru .

\section{Kata yang dibalik dengan}

\section{imbuhan}

Beberapa kata dalam osob ngalaman, yang diikuti atau didahului oleh imbuhan, proses membalik katanya barvariasi. Dari data yang telah didapatkan, ada 9 kata yang diikuti ataupun didahului oleh imbuhan.

\section{Data 9}

"Kanggo nawak nawak sam kodew hekab, osob ngalam sejarae dowo, lewat forum licek licekan iki, 
ayaz pengen lorod lorod hekab blajar osi osob has ngalam iki."

"Buat kawan-kawan cowok maupun cewek semua, Bahasa Malangan sejarahnya panajang. Lewat forum kecil-kecilan ini, saya ingin saudara-saudara semua bisa belajar bahasa khas Malang ini."
Kalimat diatas campuran bahasa Jawa dan bahasa Indonesia, yang hampir semua kata-katanya dibalik. Yang merupakan kata yang diikuti oleh imbuhan adalah kata licek-licekan.

Licek-licekan berasal dari bahasa Indonesia "kecil-kecilan"

Proses pembentukan struktur katanya adalah sebagai berikut:

$\mathrm{K}$ e c i $1-\mathrm{k}$ e $\mathrm{c}$ i $1+$ an $\rightarrow 1$ i c e $\mathrm{k}-1$ i c e $\mathrm{k}+$ an

$K_{1} V_{1} K_{2} V_{2} K_{3}-K_{1} V_{1} K_{2} V_{2} K_{3}+$ an $\rightarrow K_{3} V_{2} K_{2} V_{1} K_{1}-K_{3} V_{2} K_{2} V_{1} K_{1}+$ an

Kata bentukan ini yang dibalik kata dasarnya, sementara imbuan -an nya tetap berada diposisi yang sama.

\section{Data 10}

"Nuwus hebak Dulur. Mugomugo sing njawab makin lancar usahane ambek ojrek $e^{\prime \prime}$

"Terima kasih Saudara semua.Semoga yang menjawab semakin lancar usaha dan kerjanya."

Kalimat dalam data 10, yang termasuk dalam kata bentukan Osob Ngalaman dan diikuti oleh imbuhan adalah kata ojreke.

Kata ojreke berasal dari bahasa Jawa kerjoe artinya kerjanya.

Proses pembentukan struktur katanya adalah sebagai berikut:
$\mathrm{K}$ e $\mathrm{rjo}_{\mathrm{j}}+\mathrm{e} \rightarrow \mathrm{Oj} \mathrm{r} \mathrm{e} \mathrm{k}+\mathrm{e}$ $\mathrm{K}_{1} \mathrm{~V}_{1} \mathbf{K}_{2} \mathrm{~K}_{3} \mathrm{~V}_{2}+\mathrm{e} \rightarrow \mathrm{V}_{2} \mathrm{~K}_{3} \mathrm{~K}_{2} \mathrm{~V}_{1} \mathbf{K}_{1}+\mathrm{e}$

Kata bentukan ini yang dibalik kata dasarnya, sementara imbuan -e nya tetap berada diposisi yang sama.

Data 11

"Ogese ngarambes penting ombene ipok sanap"

"Nasinya sembarang penting minumnya kopi panas."

Kalimat dalam data 11 terdiri dari bahasa Indonesia (penting) dan bahasa Jawa (Ogese, ngarambes, ombene, ipok, sanap) dan kata yang diikuti imbuhan adalah Ogese.

Ogese berasal dari bahasa Jawa Sego e yang artinya adalah Nasi nya. 
Proses pembentukan struktur katanya adalah sebagai berikut:

$\mathrm{S}$ e $\mathrm{g} \mathrm{o}^{+} \mathrm{e} \rightarrow \mathrm{Og}$ e st e

$\mathbf{K}_{1} \mathrm{~V}_{1} \mathbf{K}_{2} \mathrm{~V}_{2}+\mathrm{e} \rightarrow \mathrm{V}_{2} \mathbf{K}_{2} \mathrm{~V}_{1} \mathbf{K}_{1}+\mathrm{e}$

Kata bentukan ini yang dibalik kata dasarnya, sementara imbuan -e nya tetap berada diposisi yang sama.

\section{Data 12} iyep?"

"Rabak e ayas kipa. Lha nek umak

"Kabar saya baik. Kabar kamu gimana?"

Kalimat dalam data 12, yang termasuk dalam kata bentukan Osob Ngalaman dan diikuti oleh imbuhan adalah kata rabake.

Kata rabake berasal dari bahasa Jawa kabare artinya kabarnya.

Proses pembentukan struktur katanya adalah sebagai berikut:

$\mathrm{Ka} \mathrm{b}$ a $\mathrm{r}+\mathrm{e} \rightarrow \mathrm{R}$ a b a $\mathrm{k}+\mathrm{e}$ $K_{1} V_{1} K_{2} V_{2} K_{3}+e \rightarrow K_{3} V_{2} K_{2} V_{1} K_{1}+e$

Kata bentukan ini yang dibalik kata dasarnya, sementara imbuan -e nya tetap berada diposisi yang sama.

Ada satu kata yang diikuti oleh imbuhan dan imbuhannya berubah posisi ikut dibalik urutan struktur hurufnya, seperti terdapat pada data 7 berikut ini.

Data 7

"Tem ingeb ker, yokpo erabak arema ngalam ongis nade oy.."

" Mat malam teman, Gimana

kabar Arema Malang singo edan..oy"

Kalimat dalam data 7 hampir semua kata-katanya dirubah menjadi osob ngalaman. Satu kata yang diikuti imbuhan adalah erabak.

Kata erabak berasal dari bahasa Jawa kabare artinya kabarnya.

Proses pembentukan struktur katanya adalah sebagai berikut:

$\mathrm{Ka} \mathrm{b}$ a $\mathrm{r}+\mathrm{e} \rightarrow$ e + r a b a $\mathrm{k}$ $\mathbf{K}_{1} \mathrm{~V}_{1} \mathbf{K}_{2} \mathrm{~V}_{2} \mathrm{~K}_{3}+$ e $\rightarrow$ e $\mathrm{K}_{3} \mathrm{~V}_{2} \mathbf{K}_{2} \mathrm{~V}_{1} \mathbf{K}_{1}$

Kata bentukan ini tidak hanya kata dasarnya yang dibalik urutan struktur hurufnya, imbuan -e nya pun ikut berubah di awal kata.

D. Pola lainnya

Selain pola pembentukan di atas, ditemukan juga proses pembalikan yang berbeda dengan proses sebelumnya. Seperti pada data berikut ini

\section{Data 14}

"Sing kadit kane dikiwal, ojok dikiwal jes, kadit kane krungune he he" 
“Yang tidak enak dibalik, jangan di balik Bung, tidak enak kedengarannya, he he"

Berikut struktur pembentukan

Dari kalimat di atas yang berbeda pembentukannya adalah kata dikiwal yang merupakan bentukan dari bahasa Jawa diwalik yang artinya "dibalik".

Prosesnya adalah sebagai berikut:

$\mathrm{di}+\mathrm{w}$ a 1 i $\mathrm{k} \rightarrow \mathrm{di}+\mathrm{k}$ i $-\mathrm{w}$ a 1

$\mathrm{di}+\mathrm{K}_{1} \mathrm{~V}_{1} \mathrm{~K}_{2} \mathrm{~V}_{2} \mathrm{~K}_{3} \rightarrow \mathrm{di}+\mathrm{K}_{3} \mathrm{~V}_{2}-\mathrm{K}_{1} \mathrm{~V}_{1} \mathrm{~K}_{2}$

dalam proses di atas, imbuhan ditetap berada pada awal kata, sementara kata dasar walik berubah menjadi ki-wal. "Ki" merupakan kebalikan dari 2 huruf terakhir "ik", sementara kata "wal" tetap seperti urutan aslinya. Tatapi letak suku katanya yang awalnya di depan menjadi terletak dibelakang.

\section{Data 15}

"Ker lek umak onok wektu lek osi tulung di ewangi, nawak ewed ewag penelitian osob kiwalan."

"Bung, kalau kamu ada waktu kalau bisa tolong dibantu, kawan sendiri bikin penelitian Osob kiwalan."

Dari kalimat di atas yang berbeda pembentukannya adalah kata kiwal-an yang merupakan bentukan dari bahasa Jawa walikan yang artinya "kebalikan". kata tersebut:

$\mathrm{w}$ a 1 i $\mathrm{k}+\mathrm{an} \rightarrow \mathrm{k}$ i $-\mathrm{w}$ a $1+$ an

$\mathrm{K}_{1} \mathrm{~V}_{1} \mathrm{~K}_{2} \mathrm{~V}_{2} \mathrm{~K}_{3}+\mathrm{an} \rightarrow \mathrm{K}_{3} \mathrm{~V}_{2}-\mathrm{K}_{1} \mathrm{~V}_{1} \mathrm{~K}_{2}+$ an

dalam proses di atas, imbuhan -an tetap berada pada akhir kata, sementara kata dasar walik berubah menjadi ki-wal. "Ki" merupakan kebalikan dari 2 huruf terakhir "ik", sementara kata "wal" tetap seperti urutan aslinya. Tatapi letak suku katanya yang awalnya di depan menjadi terletak dibelakang.

\section{Data 9}

"Kanggo nawak nawak sam kodew hekab, osob ngalam sejarae dowo"

"Buat kawan-kawan cowok dan cewek semua, $\mathrm{Osob}$ Ngalam sejarahnya panjang."

Dalam data 9 ini kata yang pembentukannya berbeda atau tidak dibalik semua urutan hurufnya adalah kata hekab yang berasal dari bahasa Jawa kabeh dan mempunyai arti semua.

Proses pembentukannya adalah sebagai berikut:

$\mathrm{K}$ a b e $\mathrm{h} \rightarrow \mathrm{h}$ e $-\mathrm{k}$ a b 
$\mathrm{K}_{1} \mathrm{~V}_{1} \mathrm{~K}_{2} \mathrm{~V}_{2} \mathrm{~K}_{3} \rightarrow \mathrm{K}_{3} \mathrm{~V}_{2}-\mathrm{K}_{1} \mathrm{~V}_{1} \mathrm{~K}_{2}$

Kata asal kabeh berubah menjadi hekab. "he" merupakan kebalikan dari 2 huruf terakhir "eh", sementara kata " $k a b$ " tetap seperti urutan aslinya. Tatapi letak suku katanya yang awalnya di depan menjadi terletak dibelakang.

Dari temuan tersebut dapat diambil kesimpulan cara membalik kata-kata dalam osob malangan bervariasi. Kata kabeh bisa menjadi hebak dibalik seluruh hurufnya, bisa juga menjadi hekab yang berbeda cara membaliknya.

\section{F. Penggunaan Osob Ngalaman dalam Nama Diri dan Nama} Tempat

Hal menarik lagi adalah Osob ngalaman juga digunakan dalam Nama diri maupun nama Tempat, seperti yang ada dalam data temuan adalah sebagai berikut:

Untuk penggunaan nama dapat dianalisa ada yang membalik seluruh nama nya, tetapi urutan namanya tetap.

Seluruh Nama dibalik : : Amrahd Idub Amusuk $\quad \rightarrow$ Dharma Budi Kusuma
Ada juga yang hanya membalik salah satu bagian dari namanya

Dibalik sebagian:

Oyranus Coki $\rightarrow$ Sunaryo Coki Eddy Nawanug $\rightarrow$ Eddy Gunawan Ada juga yang mencampurkan dengan kata lain:

Campuran : Onot Jenenge Ramus Jenenge Sumartono Untuk Nama Wilayah yang diganti dengan Osob Ngalaman adalah sebagai berikut:

$$
\begin{aligned}
& \text { Naurusap } \rightarrow \text { Pasuruan, } \\
& \text { Kisreg } \rightarrow \text { Gresik, } \\
& \text { Nenjap } \rightarrow \text { Panjen }
\end{aligned}
$$

Yang menarik adalah ketiga nya cara membalik kata- katanya berbeda.

Urutan huruf dibalik semua.

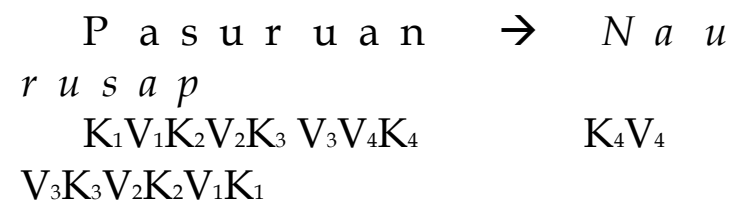

Ada perubahan dari kata Gres-ik menjadi Ki-sreg.

Gresik $\rightarrow \quad$ Kisreg

$\mathrm{K}_{1} \mathrm{~K}_{2} \mathrm{~V}_{1} \mathrm{~K}_{3} \mathrm{~V}_{2} \mathrm{~K}_{4} \quad \mathrm{~K}_{4} \mathrm{~V}_{2}$ $\mathrm{K}_{3} \mathrm{~K}_{2} \mathrm{~V}_{1} \mathrm{~K}_{1}$

Sebagian huruf tidak dibalik $\mathrm{K}_{2} \mathrm{~K}_{3}$ (nj) tetap $\mathrm{K}_{2} \mathrm{~K}_{3}$ (nj). $\mathrm{P}$ a $\mathrm{n} \mathrm{j} \mathrm{e} \mathrm{n} \rightarrow \quad N e n j a p$ $\mathrm{K}_{1} \mathrm{~V}_{1} \mathrm{~K}_{2} \mathrm{~K}_{3} \mathrm{~V}_{2} \mathrm{~K}_{4} \quad \mathrm{~K}_{4} \mathrm{~V}_{2} \mathrm{~K}_{2} \mathrm{~K}_{3} \mathrm{~V}_{1} \mathrm{~K}_{1}$ 
Dalam kalimat pada data ini

Penggunaan osob Malangan untuk nama baik nama diri maupun nama wilayah juga mempunyai ciri khas yang berbeda seperti kata Gres menjadi Serg. Konsonan $n j$ tetap $n j$.

\section{F. Kata-Kata Baru}

Dalam data yang telah didapatkan, ada kata-kata yang bukan berasal dari mambalik kata-kata tertentu, tetapi merupakan kata baru dalam osob ngalaman. Kata-kata tersebut ada dalam data-data berikut ini:

\section{Data 16}

"Wez genaro2 gulemo ngiseb tok, Yo ngene iki garai ojir sibun."

"Wah orang-orang maunya ngiseb aja, ya begini ini yang bikin uang menipis."

Dalam kalimat diatas terdapat 3 kata baru yang merupakan kata-kata asli osob ngalaman, yaitu genaro yang berarti orang, ojir yang berarti uang, dan sibun yang berarti habis atau menipis.

\section{Data 17}

"Arek semok iki tak lawet, Spek; semok, sinam, bahenol.."

"Anak seksi ini saya jual, spek nya, seksi, manis, bahenol." terdiri dari tiga bahasa yaitu bahasa Jawa, bahasa Indonesia dan bahasa Inggris, dari kata-kata tersebut terdapat kata baru asli osob ngalaman yaitu kata lawet yang berarti jual.

\section{G. Semua kata dibalik}

Dari 43 kalimat dalam data ada yang berasal dari 1 bahasa, 2 bahasa bahkan 3 bahasa (Bahasa Jawa, Bahasa Indonesia, dan Bahasa Inggris) hanya ada 5 kalimat yang seluruh katakatanya dibalik. Dan 38 kalimat tidak semua kata-katanya dibalik. Jumlah kata-kata yang dibalik juga variatif tergantung penuturnya. Berikut adalah kalimat yang seluruh katakatanya dibalik 


\section{Data 18}

Seluruh kata-kata nya dari bahasa Jawa.

"Kisreg nadu nasipes. Ikias siw kodor reges"

"Gresik udan sepisan. Saiki wis rodok seger"

"Gresik hujan sekali. Sekarang sudah sedikit segar."

\section{Data 19}

Seluruh kata-katanya dari bahasa Indonesia.

"Uka kadit itreng Sam"

\section{Data 20}

"Aku tidak ngerti Mas"

Kata-kata nya dari bahasa Jawa dan bahasa Indonesia

"Umak iki naekak ayag, terbmaj necna."

"Kamu iki kakean gaya, jambret ancen"

"Kami ini kebanyakan gaya, memang jambret

(umpatan dalam bahasa Jawa)."

\section{KESIMPULAN HASIL PENELITIAN}

Osob Ngalaman atau Bahasa Khas

Malangan merupakan bahasa yang masih eksis digunakan oleh anak-anak muda Malang. Dari hasil analisis data yang di akses melalui komunitas social network (Face book) dapat ditarik kesimpulan sebagai berikut:

1. Struktur kata dalam Osob ngalaman, ada berbagai macam struktur, bahkan karena tidak ada aturan dari kata yang sama anatara penutur yang satu dan yang lainnya membalik kata dengan proses yang berbeda sehingga memunculkan kata yang berbeda. Pola tersebut antara lain:

a. Kata yang dibalik langsung seluruh hurufnya $\left(\mathrm{K}_{1} \mathrm{~V}_{1} \mathrm{~K}_{2} \mathrm{~V}_{2} \mathrm{~K}_{3} \rightarrow\right.$ $\mathrm{K}_{3} \mathrm{~V}_{2} \mathrm{~K}_{2} \mathrm{~V}_{1} \mathrm{~K}_{1}$ )

b. Kata yang sebagian suku katanya tidak dibalik.

$\left(\mathrm{K}_{1} \mathrm{~K}_{2} \mathrm{~V}_{1} \mathrm{~K}_{3} \mathrm{~K}_{4} \mathrm{~V}_{2} \rightarrow \mathrm{V}_{2} \mathrm{~K}_{4} \mathrm{~K}_{3} \mathrm{~V}_{1} \mathrm{~K}_{1} \mathrm{~K}_{2}\right)$

c. Kata yang diikuti imbuhan, baik awalan atau akhiran, yang dibalik hanya kata dasarnya saja, sementara imbuhannya tetap berada pada posisi yang sama.

$$
\begin{aligned}
& \text { Imbuhan }+ \text { K1V1K2V2 } \rightarrow \\
& \text { Imbuhan + V2 K2V1 K1 }
\end{aligned}
$$


K1V1K2V2 + Imbuhan $\rightarrow$

V2 K2V1 K1 + Imbuhan

d. Ada satu kata yang diikuti oleh imbuhan dan imbuhannya berubah posisi ikut dibalik urutan struktur hurufnya

Imbuhan $+\mathrm{K} 1 \mathrm{~V} 1 \mathrm{~K} 2 \mathrm{~V} 2 \rightarrow \mathrm{V} 2$

K2V1 K1 + Imbuhan

e. Ada pola lain yang proses membaliknya berbeda yaitu:

$\mathrm{K}_{1} \mathrm{~V}_{1} \mathrm{~K}_{2} \mathrm{~V}_{2} \mathrm{~K}_{3} \quad \rightarrow \mathrm{K}_{3} \mathrm{~V}_{2}-\mathrm{K}_{1} \mathrm{~V}_{1} \mathrm{~K}_{2}$

2. Osob Ngalaman dalam juga dunakan untuk Nama Diri dan Nama Tempat, Untuk nama diri dengan susunan pola kata seluruh nama dibalik, yang dibalik hanya salah satu bagian dari namanya, atau mencampurkan dengan kata lain. Untuk nama tempat, ada yang dibalik seluruh huruf, ada yang sebagian huruf tetap tidak dibalik.

3. Selain membalik urutan huruf dalam kata-kata, dalam Osob Ngalaman juga terdapat kata-kata asli antara lain: Genaro, Ojir, Lawet, Sibun.

4. Osob ngalaman bisa menggunakan kata-kata dari 1 bahasa, 2 bahasa bahkan 3 bahasa (Bahasa Jawa, Bahasa Indonesia, dan Bahasa Inggris). Dari 43 kalimat temuan hanya ada 5 kalimat yang seluruh kata-katanya dibalik. Dan 38 kalimat tidak semua kata-katanya dibalik. Jumlah kata-kata yang dibalik juga variatif tergantung penuturnya.

\section{PERLUNYA PENDIRIAN OSOB NGLAMAN CENTER}

Hasil penelitian di atas tidak akan ada artinya kalau hanya berhenti sebatas penelitian. Untuk itu perlu dibentuk atau didirikan Lembaga atau Pusat Osob Ngalaman Center. Lembaga ini mempunyai tugas utama:

a. mendokumentasikan Osob Ngalaman

b. melakukan studi terus-menerus terhadap perkembangan Osob Ngalaman

c. merumuskan buku ajar sederhana, dan sekaligus membuat kamus Osob Ngalaman

d. menjadi pusat pembelajaran Osob Ngalaman.

e. merancang dan merencanakan penggunaan Osob Ngalaman sebagai sarana Promosi Wisata Malang.

Dengan adanya OSOB NGLAMAN CENTER ini diharapkan penggunaan 
atau keberadaan bahasa khas Malang ini akan menjadi ciri khas utama yang sangat mengesankan bagi wisatawan. Dan menjadi daya tarik tersendiri baik bagi wisatawan domestik maupun manca negara.

\section{DAFTAR PUSTAKA}

Adi Lassta, Fakta Boso Ngalaman ,April 28,2011

Arifin, Bustanul.1996. Pengantar Analisis Wacana. Malang: Depertemen Pendidikan dan Kebudayaan IKIP Malang.

Chaer, Abdul. 2007. Kajian Bahasa: Struktur Internal, Pemakaian, dan Pemelajaran.Jakarta: Rineka Cipta.

Chaer, Abdul dan L. Agustina. 2004. Sosiolinguistik: Perkenalan Awal. Jakarta: Rineka Cipta.

Devito, Joseph, A. 1997. Komunikasi Antar Manusia, Kuliah Dasar. Penerjemah: Agus Maulana. Jakarta: Profesional Books.

Facebook,

(https://www.facebook.com/gr oups/180218532021941/ ?fref=ts:

diakses 09 Juni 2015: 00.01)

Kampuspedia,http://kampuspedia.bl ogspot.com/2012/01/daftaruniversitas-di-kota-malang. diakses 08 Juni 2015: 08.00

Osobngalaman, http://osobngalam.blogspot.com /2011/03/normal-0-false-falsefalse-in-x-none-x.html diakses 09 juni $2015: 23.55$

Sihabudin, Ahmad. 2011. Komunikasi Antar Budaya. Jakarta: Bumi Aksara.

Soenarno, Adi. 2010. Kamus Bahasa Malangan. Malang: Indy.

Sumarsono dan Partana, Paina. 2004. Sosiolinguistik. Yogyakarta: Sabda bekerja sama dengan Pustaka Pelajar

Turuntanganmlg, https://turuntanganmlg.wordpr ess.com/2015/02/26/sejarahawal-bahasa-walikan/ diakses 08 Juni 2015: 08.05

Web Kota Malang, http:/ / malangkota.go.id/fasilitasdaerah/pendidikan/perguruan-tinggi. 